\title{
Comparative Slaughter Performance and Meat Quality of Rutana, Gumuz and Washera Sheep of Ethiopia Supplemented with Different Levels of Concentrate
}

\author{
Anteneh Worku ${ }^{1 *}$, Mengistu Urge ${ }^{2}$, Getachew Animut ${ }^{3}$, Getnet Asefa ${ }^{4}$ \\ ${ }^{1}$ Department of Animal Sciences, Debre Markos University, Debre Markos, Ethiopia \\ ${ }^{2}$ School of Animal and Range Sciences, Haramaya University, Dire Dawa, Ethiopia \\ ${ }^{3}$ Agriculture Transformation Agency, Addis Ababa, Ethiopia \\ ${ }^{4}$ Ethiopian Institute of Agricultural Research, Addis Ababa, Ethiopia \\ Email: *antenehworku7@gmail.com
}

How to cite this paper: Worku, A., Urge, M., Animut, G. and Asefa, G. (2020) Comparative Slaughter Performance and Meat Quality of Rutana, Gumuz and Washera Sheep of Ethiopia Supplemented with Different Levels of Concentrate. Open Journal of Animal Sciences, 10, 48-63.

https://doi.org/10.4236/ojas.2020.101005

Received: November 18, 2019

Accepted: December 20, 2019

Published: December 23, 2019

Copyright $\odot 2020$ by author(s) and Scientific Research Publishing Inc. This work is licensed under the Creative Commons Attribution International License (CC BY 4.0).

http://creativecommons.org/licenses/by/4.0/

(c) (i) Open Access

\begin{abstract}
A study was conducted to compare the carcass yield and meat quality of $\mathrm{Ru}$ tana, Gumuz and Washera sheep of Ethiopia under two concentrate supplement levels (CSL), low (300 g/day) and high (450 g/day). The supplement contains $45 \%$ wheat bran, $26 \%$ maize grain and $29 \%$ Noug cake. A total of 36 sheep (12 from each genotype) were used in $3 \times 2$ factorial treatment arrangement (3 genotypes and $2 \mathrm{CSL}$ ) which was used in a completely randomized block design. Hay was fed ad libitum at a rate of $20 \%$ refusal. After the completion of 90 days fattening period, all sheep were slaughtered and meat sample from longissimus dorsi muscle of each animal was taken for sensory evaluation and instrumental measurement of tenderness and for color, $\mathrm{pH}$, and chemical composition analysis. Slaughter body weight (SBW) (26.0 vs. $24.1 \mathrm{~kg}$ ), hot carcass weight (HCW) (11.3 vs. $9.7 \mathrm{~kg}$ ), dressing percentage (DP) on SBW (43.4\% vs. $40.1 \%$ ) and EBW basis (53.6\% vs. $50.9 \%)$, and rib eye-muscle (REM) were higher for the high than low CSL. Rutana sheep had heavier HCW $(11.9 \mathrm{~kg})$ than Gumuz $(10.1 \mathrm{~kg})$ and Washera $(9.4 \mathrm{~kg})$ sheep. DP on EBW basis was higher for Rutana (54.7) than Washera sheep (48.1), while the value for Gumuz (50.9) was similar with both genotypes. Meat from high supplemented sheep had higher fat (9.7\% vs. $8.8 \%)$, tenderness, juiciness, flavor and lower shear forces than the low level of supplementation. Most sensory parameters measured were in the order of Rutana $>$ Gumuz $>$ Washera sheep. It is concluded that Rutana sheep were relatively more suitable than Gumuz and Washera sheep for production of better carcass yield. The potential of Washera sheep to produce more carcass yield relative to their
\end{abstract}


HCW, SBW and EBW was comparable with that of Gumuz sheep.

\section{Keywords}

Dressing Percentage, Carcass and Non-Caracara Parameters, Meat Color, Proximate Compositions, Sensory Evaluation, Shear Force, Supplement, Sheep

\section{Introduction}

Ethiopia is believed to be one of the major gateways for domestic sheep migration from Asia into Africa [1]. With 31.30 million sheep [2] and 14 traditional populations [3], there are highly diversified indigenous sheep types which are parallel to the diversity in ecology [4]. In Ethiopia major groups are classified into four namely; short fat-tailed sheep, long fat-tailed, fat-rumped sheep, thin-tailed sheep [5]. Gumuz and Rutana sheep breeds are categorized under the thin-tailed sheep whereas Washera sheep is categorized under short fat-tailed sheep [5]. The three breeds are found in Amhara and Benishangul-Gumz Regional States [3] [6]. Washera sheep has fast growth rate under harsh circumstances [7]. Gumuz breed is the most preferred breed because of its adaptation to hot climate, faster growth and higher prolificacy [8]. Rutana is a desert sheep in the Sudan and is kept mainly for meat production, and is preferred in the border markets in western Ethiopia for export due to its higher growth potential and big size [6] [9].

Carcass and non-carcass components are the slaughtering results of animals [10]. There is performance difference in carcass characteristic and meat quality of sheep as documented in a comparative study conducted in Ethiopian sheep and goat. The carcass weight for Black head Ogaden, Horro and Washera sheep was $9.7 \mathrm{~kg}, 11.7 \mathrm{~kg}$ and $10.5 \mathrm{~kg}$, respectively recorded for comparative study of sheep in Ethiopia [11]. Dereje et al. [12] reported that the carcass weight for Bati, Hararghe highland goat, Short-eared Somali goat were $7.8 \mathrm{~kg}, 8.3 \mathrm{~kg}, 7.2 \mathrm{~kg}$, respectively. Generally, the average carcass weight of Ethiopian sheep and goats is relatively low, which could be because of poor genetic performance, poor animal husbandry practices, or a combination [13]. Generally, comparative research work dealing with breed characterization for meat production potential and other production traits for sheep is limited. Future research on breed characterization by exploiting their maximum potential under various feeding management is needed [11]. The comparative performance evaluation of Rutana, Gumuz and Washera sheep breeds of Ethiopia at feedlot with supplementation of concentrates appears to be lacking. Thus, the objectives of the study were evaluating the difference in carcass and non-carcass characteristics, and meat quality of Rutana, Gumuz and Washera sheep kept under two levels of concentrate supplementation. 


\section{Materials and Methods}

\subsection{Experimental Animal Management and Treatments}

The study was conducted at Burie campus of Debre-Markos University, Ethiopia located at latitude of $10^{\circ} 42^{\prime} \mathrm{N}$ and longitude of $37^{\circ} 4^{\prime} \mathrm{E}$. The altitude of the area is 2091 meter above sea level, annual rainfall is $1500 \mathrm{~mm}$ and the mean temperature is $22^{\circ} \mathrm{C}$ [14]. A total of 36 intact male sheep of three genotypes, Rutana, Gumuz and Washera of about 8 - 10 months of ages, 12 from each genotybe were purchased from local markets where each breed is found. The age was estimated by asking the owners and checking the pattern of eruption of the incisor teeth of the sheep [15]. Animals were quarantined for 3 weeks during which time they were vaccinated for ovine pasteurellosis and sheep pox. Animals were also injected with Ivermectin as a broad spectrum treatment against internal and external parasites, and de-warmed with Albendazole mainly against the adult stages of internal parasites. At the end of the quarantine, each sheep was weighed and placed in an individual pen and acclimated to the environment and experimental condition for 2 weeks, which was followed by 90 days of feeding trial and 10 days of digestibility trial.

Experimental treatments were arranged in a three by two factorial arrangement in a completely randomized block design. There were three genotypes (Rutana, Washera and Gumuz sheep) and two levels of concentrate supplementation (300 and $450 \mathrm{~g} \mathrm{DM} /$ day/head of concentrate mix). Animals within genotype were blocked based on their initial body weight and randomly assigned to one of concentrate supplementation levels each consisting six animals. The experiment feeds consisted of mixed sward natural pasture hay as a basal diet and concentrate mix as a supplement. The hay was manually chopped to about $2.5 \mathrm{~cm}$ sizes and fed ad libitum ensuring a refusal of $20 \%$ with the amount offered being adjusted once every $3^{\text {rd }}$ day. The concentrate mix consists of $45 \%$ wheat bran, $26 \%$ maize grain and $29 \%$ Noug seed cake, and was formulated to have about $22.3 \%$ CP to fulfill the requirements of growing lambs [16]. The chemical composition of the concentrate mix and the hay is given in Table 1. The concentrate was offered twice a day in two equal portions at 0800 and 1600 hours. Clean water and salt lick were available all the time.

Table 1. Chemical composition (\% for DM and \% DM for others) of experimental feeds.

\begin{tabular}{cccccc}
\hline Dietary ingredients & DM & OM & CP & NDF & ADF \\
\hline Hay & 93.1 & 90.1 & 7.9 & 80.2 & 43.1 \\
Concentrate mix & 91.9 & 91.9 & 21.0 & 36.2 & 15.9 \\
Maize grain & 88.1 & 98.2 & 7.9 & 25.2 & 7.9 \\
Wheat bran & 90.7 & 89.8 & 17.9 & 45.1 & 14.4 \\
Noug seed cake & 91.6 & 91.8 & 31.9 & 32.6 & 27.4 \\
\hline
\end{tabular}

$\mathrm{DM}=$ Dry matter; $\mathrm{OM}=$ Organic matter $\mathrm{CP}=$ Crude protein $; \mathrm{NDF}=$ Neutral detergent fiber; $\mathrm{ADF}=\mathrm{Acid}$ detergent fiber; Concentrate Mix = Wheat bran (45\%), maize grain (26\%) and Noug seed cake (29\%). 


\subsection{Animal Slaughter and Carcass Measurements}

At the end of the feeding trial, sheep were fasted for 12 hours overnight with free access to water. Slaughter body weight (SBW) was then measured and all sheep were slaughtered to determine carcass characteristics. The blood was drained into a bucket and weighed. After removal of digestive tract and non-carcass components, hot carcass weight $(\mathrm{HCW})$ was recorded including tail fat. Edible (heart, liver, kidney, blood, digestive organs, total fat) and non-edible (skin, head, feet, spleen, lungs, trachea, genitalia) non-carcass components were weighed separately and recorded. Digestive tract was weighed while full and empty. The weight of digesta was computed as the difference between full and empty digestive tract. The empty body weight (EBW) was determined as SBW less gut contents. Dressing percentage (DP) was calculated as (HCW/SBW) $\times$ 100 and $(\mathrm{HCW} / \mathrm{EBW}) \times 100$. Rib eye-muscle area $(\mathrm{REM})$ was measured the $12 / 13^{\text {th }}$ rib position of Longissimus dorsi muscle (LDM) using transparent paper. The left and right rib-eye muscle area were traced onto a square paper and the area of the squares that fell within the traced area was counted and those partially fell outside was estimated. The average of the two sides was taken as the REM. Kidney, scrotal, pelvic, and heart fat weight measurements were taken using a balance of sensitivity $0.01 \mathrm{~kg}$ and summed up as a non-carcass fat.

\subsection{Sampling and Chemical Analysis of Feed and Meat Samples}

Feed and dietary ingredients were sampled weekly during the feeding trial and composited for chemical analysis. Samples were dried at $60^{\circ} \mathrm{C}$ for 72 hours, and ground using laboratory mill to pass $1 \mathrm{~mm}$ screen. The samples were analyzed for dry matter (DM), nitrogen (N), ash [17], acid detergent fiber (ADF), and neutral detergent fiber (NDF) [18]. The CP was calculated as $\mathrm{N}^{\star} 6.25$.

Meat samples were taken from areas of LDM at $10^{\text {th }}$ to $13^{\text {th }}$ rib positions, chopped and thoroughly mixed and frozen at $-20^{\circ} \mathrm{C}$ until partially dried. The frozen fresh samples were partially dried at $55^{\circ} \mathrm{C}$ for 72 hours, packed in polyethylene bags and stored in a refrigerator at $4^{\circ} \mathrm{C}$ pending proximate chemical analysis. About $2 \mathrm{~g}$ of partially dried samples were weighed into a pre-weighed crucible dish, and dried in an oven at $102^{\circ} \mathrm{C}$ overnight to determine DM. Ashing was carried out at $600^{\circ} \mathrm{C}$ for 6 hours. The rest of the sample materials were oven-dried, ground and stored in a refrigerator at $4^{\circ} \mathrm{C}$ until required for analysis of protein and fat percentages. Total fat was extracted using Soxhlet apparatus for 6 hour with diethyl ether (boiling point of $34.5^{\circ} \mathrm{C}$ ) and the dried residue was weighed for fat content. Crude protein was determined according the method outlined by AOAC [17].

\subsection{Meat $\mathrm{pH}$ and Color Measurements}

Meat samples taken from LDM for proximate analysis were used for color and $\mathrm{pH}$ measurements. The $\mathrm{pH}$ measurements were made 1 and 24 (ultimate) hours after slaughter using portable pH-meter (Meat PH meter-HI99163, HANAN instruments) having sharp penetrating electrode. The probe was cleaned with dis- 
tilled water and calibrated with $\mathrm{pH} 4.1$ and 7.1 standard buffer solutions between sample measurements. For meat color measurements, the cut surface of frozen samples at $4^{\circ} \mathrm{C}$ was freshly exposed on flat surface of white background and allowed to bloom for about $30-45$ minutes at ambient temperature. Then, meat color parameters i.e., CIE $\mathrm{L}^{*} \mathrm{a}^{*} \mathrm{~b}^{*}$ values $\left(\mathrm{L}^{*}=\right.$ lightness, $\mathrm{a}^{*}=$ redness and $\mathrm{b}^{*}=$ yellowness) were obtained using the digital colorimeter (HunterLab MiniScan EZ, Serial No. MsEZ1547, 45/0 illumination/viewing system, D65 light source, and $10^{\circ}$ observer angle) calibrated with black and white standardized calibration plates between sample measurements [19]. Three random readings at different locations per sample were taken and averaged.

\subsection{Sensory Evaluation of Meat}

Meat samples taken from LDM muscle were evaluated for tenderness, juiciness, flavor and overall acceptability by semi trained twelve panelists following the standard procedure [20]. The samples were cut into pieces and wrapped individually in aluminum foil and roasted in an oven at $125^{\circ} \mathrm{C}$ for 45 minutes. Then, the roasted samples were cut into uniform bite-size pieces and kept in food warmers until evaluated by panelists. Pieces from each sample per breed were provided to panelists randomly in such a way that everyone got sample from each breed and muscle type. The panelists independently rated the tasted samples on a nine-point hedonic scale for Tenderness from Extremely Tender $=7$ to Extremely Tough $=1$; Juiciness from Extremely Juicy $=7$ to Extremely Dry $=1$; Flavor from Extremely Desirable $=7$ to Extremely Poor $=1$, and General Acceptability from Extremely Liked $=7$ to Extremely Dislike $=1$.

\subsection{Warner-Bratzler Shear Force Test to Determining Tenderness of Meat Samples}

The steaks were prepared according to procedures develop earlier [21]. Each batch of aged samples was thawed for 24 hours at room temperature $\left(24^{\circ} \mathrm{C}\right.$ $25^{\circ} \mathrm{C}$ ) for steaks preparation. The Warner-Bratzler shear force method was used to determine objective tenderness [20]. The steak was allowed to cool down to room temperature prior for about an hour to evaluate instrumental tenderness using WBSF. After cooling, the steak was cut across the long axis putting the knife tip on heavy connective tissue side (dorsal) and handle of knife on ventral side in order to expose the fiber direction. Six cores were removed parallel with the muscle fibers. It was critical that the muscle fibers run parallel with the core so that the shear was across the grain. The WBSF device was used to shear each core. The shear was across the middle (center) on each core. The peak values of WBSF were recorded in $\mathrm{N}$ (Newton) for each core. The values for the seven cores were averaged for the determination of a single value for each steak.

\subsection{Statistical Analysis}

Data were analyzed using the general linear model GLM procedure of SAS [22]. Adjusted Tukey test was used to locate the significant differences between means 
when F-test declare significance at $\mathrm{p}<0.05$. The statistical model used was: $Y_{i j k l}$ $=\mu+B_{i}+S_{j}+C_{k}+(B \times C)_{j k}+e_{i j k l}$. Where: $Y_{i j k l}=$ the response variable; $\mu=$ overall mean; $B_{i}=$ effect of block; $S_{j}=$ effect of genotype; $C_{k}=$ effect of concentrate level; $(B \times C)_{j k}=$ interaction between genotype and concentrate level, and $e_{i j k l}=$ random error. Since interaction between genotype and supplement level for all attributes evaluated were not statistically significant $(p>0.05)$, only means for main effects were presented and discussed.

\section{Result}

\subsection{Carcass Weight and Dressing Percentages}

Rutana sheep had higher $(p<0.05)$ SBW, EBW, HCW and REM area than the other two breeds (Table 2). Gumuz sheep had higher EBW $(p<0.05)$ but similar $(p>0.05)$ SBW, HCW and REM area as compared to Washera sheep. Dressing percentage both in SBW and EBW bass was higher $(\mathrm{p}<0.05)$ for Rutana than Washera sheep, while the values for Gumuz sheep were comparable with both sheep breeds. All carcass parameters indicated in Table 2 were significantly increased $(p<0.05)$ by the higher level of concentrate supplementation.

\subsection{Edible and Non-Edible Offal Components}

Effects of genotype and concentrate level on edible and non-edible carcass were significant for some parameters only (Table 3 and Table 4). Liver, empty gut, heart fat and total edible offal were consistently higher $(p<0.05)$ for Rutana compared to Washera sheep. These same parameters and total non carcass fat were greater $(p<0.05)$ for the high level of concentrate supplemented group. Among

Table 2. Carcass yield and dressing percentages of Gumuz (GU), Rutana (RU) and Washera (WA) sheep fed grass hay basal diet supplemented with two levels of concentrate mix.

\begin{tabular}{|c|c|c|c|c|c|c|c|c|c|c|}
\hline \multirow{2}{*}{ Variables } & \multicolumn{4}{|c|}{ Genotype (G) } & \multicolumn{3}{|c|}{ Concentrate level (C) } & \multicolumn{3}{|c|}{$p$-value } \\
\hline & $\mathrm{GU}$ & RU & WA & SEM & Low & High & SEM & G & $\mathrm{C}$ & $\mathrm{G} \times \mathrm{C}$ \\
\hline \multicolumn{11}{|c|}{ Carcass weight (kg) } \\
\hline SBW & $24.7^{\mathrm{b}}$ & $26.5^{\mathrm{a}}$ & $23.8^{\mathrm{b}}$ & 0.44 & $24.1^{\mathrm{b}}$ & $26.0^{\mathrm{a}}$ & 0.36 & 0.0009 & 0.0011 & 0.2694 \\
\hline EBW & $20.0^{\mathrm{b}}$ & $22.0^{\mathrm{a}}$ & $19.0^{c}$ & 0.49 & $19.2^{\mathrm{b}}$ & $21.1^{\mathrm{a}}$ & 0.40 & 0.0037 & 0.0380 & 0.2091 \\
\hline HCW & $10.1^{\mathrm{b}}$ & $11.9^{\mathrm{a}}$ & $9.4^{\mathrm{b}}$ & 0.29 & $9.7^{\mathrm{b}}$ & $11.3^{\mathrm{a}}$ & 0.23 & $<0.0001$ & $<0.0001$ & 0.3193 \\
\hline \multicolumn{11}{|c|}{ Dressing percentage on the basis of } \\
\hline EBW & $50.9^{\mathrm{ab}}$ & $54.7^{\mathrm{a}}$ & $48.1^{\mathrm{b}}$ & 0.84 & $48.8^{\mathrm{b}}$ & $53.6^{\mathrm{a}}$ & 0.69 & 0.0446 & 0.0283 & 0.0774 \\
\hline SBW & $40.9^{\mathrm{ab}}$ & $45.1^{\mathrm{a}}$ & $39.3^{\mathrm{b}}$ & 0.68 & $40.1^{\mathrm{b}}$ & $43.4^{\mathrm{a}}$ & 0.56 & 0.0066 & 0.0264 & 0.2137 \\
\hline $\operatorname{REM}\left(\mathrm{cm}^{2}\right)$ & $9.4^{\mathrm{b}}$ & $9.9^{\mathrm{a}}$ & $9.3^{\mathrm{b}}$ & 0.03 & $9.2^{\mathrm{b}}$ & $9.9^{\mathrm{a}}$ & 0.03 & $<0.0001$ & $<0.0001$ & 0.5303 \\
\hline $\begin{array}{l}\text { eans with dif } \\
\text { s); SBW = } \\
\text { ssing percent } \\
\text { \%) and Noug } \\
\text { n. }\end{array}$ & $\begin{array}{l}\text { ent su } \\
\text { ughte } \\
\text {; REN } \\
\text { ed cal }\end{array}$ & $\begin{array}{l}\text { oody } \\
=\text { Rib } \\
(29 \%\end{array}$ & eight; & $\begin{array}{l}\text { BW } \\
\text { e ar } \\
300\end{array}$ & Emp & dy $w$ & $\begin{array}{l}; \mathrm{HC} \\
\mathrm{M})= \\
/ \mathrm{d} \mathrm{C}\end{array}$ & $\begin{array}{r}=\mathrm{Hot} \\
\text { heat br }\end{array}$ & cass we & $\begin{array}{l}\text { differ ( } p \\
\text { t; DP }= \\
\text { ze grain }\end{array}$ \\
\hline
\end{tabular}


Table 3. Edible offal components of Gumuz (GU), Rutana (RU) and Washera (WA) sheep fed grass hay basal diet supplemented with two levels of concentrate mix.

\begin{tabular}{cccccccccccc}
\hline \multirow{2}{*}{ Edible offal (kg) } & \multicolumn{3}{c}{ Genotype (G) } & \multicolumn{4}{c}{ Concentrate level (C) } & \multicolumn{3}{c}{$p$-value } \\
\cline { 2 - 11 } & GU & RU & WA & SEM & Low & High & SEM & G & C & G $\times$ C \\
\hline Kidney & 0.06 & 0.05 & 0.05 & 0.007 & 0.05 & 0.06 & 0.005 & 0.48 & 0.51 & 0.70 \\
Liver & $0.39^{\mathrm{ab}}$ & $0.41^{\mathrm{a}}$ & $0.37^{\mathrm{b}}$ & 0.010 & $0.38^{\mathrm{b}}$ & $0.41^{\mathrm{a}}$ & 0.008 & 0.04 & 0.03 & 0.06 \\
Heart & 0.07 & 0.08 & 0.07 & 0.005 & 0.07 & 0.08 & 0.005 & 0.61 & 0.59 & 0.36 \\
Blood & 1.64 & 1.66 & 1.55 & 0.05 & 1.66 & 1.57 & 0.04 & 0.36 & 0.23 & 0.09 \\
GIT empty & $1.32^{\mathrm{b}}$ & $1.41^{\mathrm{a}}$ & $1.31^{\mathrm{b}}$ & 0.02 & $1.29^{\mathrm{b}}$ & $1.40^{\mathrm{a}}$ & 0.01 & 0.01 & $<0.001$ & 0.05 \\
Head \& tongue & 1.48 & 1.48 & 1.47 & 0.003 & 1.47 & 1.48 & 0.003 & 0.05 & 0.28 & 0.31 \\
Heart fat & $0.06^{\mathrm{b}}$ & $0.09^{\mathrm{a}}$ & $0.05^{\mathrm{b}}$ & 0.008 & $0.05^{\mathrm{a}}$ & $0.08^{\mathrm{b}}$ & 0.007 & 0.02 & 0.001 & 0.34 \\
Kidney fat & 0.06 & 0.05 & 0.05 & 0.005 & 0.06 & 0.05 & 0.004 & 0.38 & 0.53 & 0.87 \\
Tail & 0.07 & 0.08 & 0.07 & 0.007 & 0.06 & 0.08 & 0.006 & 0.31 & 0.12 & 0.88 \\
Omental fat & 0.38 & 0.40 & 0.32 & 0.08 & 0.27 & 0.46 & 0.06 & 0.75 & 0.05 & 0.23 \\
TNCF & 0.58 & 0.63 & 0.50 & 0.08 & $0.45^{\mathrm{b}}$ & $0.69^{\mathrm{a}}$ & 0.07 & 0.59 & 0.02 & 0.26 \\
TEO & $5.58^{\mathrm{ab}}$ & $5.76^{\mathrm{a}}$ & $5.36^{\mathrm{b}}$ & 0.10 & $5.42^{\mathrm{b}}$ & $5.71^{\mathrm{a}}$ & 0.08 & 0.04 & 0.02 & 0.15 \\
\hline
\end{tabular}

a,b Means with different superscript letter within genotype and concentrate level categories in a row differ ( $p$ $<0.05)$; GIT=gastro intestinal tract; TNCF $=$ Total non carcass fat; TEO = Total edible offal; Concentrate $\operatorname{mix}(\mathrm{CM})=$ Wheat bran (45\%), maize grain (26\%) and Noug seed cake (29\%); Low = $300 \mathrm{~g} / \mathrm{d}$ CM; High = $450 \mathrm{~g} / \mathrm{d} \mathrm{CM} ; \mathrm{SEM}=$ Standard error of the mean.

Table 4. Non-edible offal components of Gumuz (GU), Rutana (RU) and Washera (WA) sheep fed grass hay basal diet supplemented with two levels of concentrate mix.

\begin{tabular}{cccccccccccc}
\hline \multirow{2}{*}{$\begin{array}{c}\text { Non-edible offal } \\
(\mathrm{kg})\end{array}$} & \multicolumn{3}{c}{ Genotype (G) } & \multicolumn{3}{c}{ Concentrate level (C) } & \multicolumn{3}{c}{$p$-value } \\
\cline { 2 - 11 } & GU & RU & WA & SEM & Low & High & SEM & B & C & B $\times$ C \\
\hline Lung & 0.33 & 0.34 & 0.32 & 0.009 & 0.32 & 0.34 & 0.007 & 0.24 & 0.12 & 0.36 \\
Testicle & 0.19 & 0.18 & 0.22 & 0.03 & 0.1 & 0.2 & 0.02 & 0.529 & 0.05 & 0.24 \\
Penis & $0.03^{\mathrm{a}}$ & $0.03^{\mathrm{a}}$ & $0.02^{\mathrm{b}}$ & 0.001 & $0.02^{\mathrm{b}}$ & $0.03^{\mathrm{a}}$ & 0.001 & $<0.0001$ & 0.005 & 0.66 \\
Spleen & $0.01^{\mathrm{b}}$ & $0.02^{\mathrm{a}}$ & $0.01^{\mathrm{c}}$ & 0.002 & $0.01^{\mathrm{b}}$ & $0.02^{\mathrm{a}}$ & 0.001 & $<0.0001$ & 0.002 & 0.74 \\
Esophagus & 0.024 & 0.023 & 0.022 & 0.007 & 0.023 & 0.024 & 0.006 & 0.74 & 0.67 & 0.17 \\
Skin \& leg & $3.2^{\mathrm{a}}$ & $3.4^{\mathrm{b}}$ & $3.1^{\mathrm{b}}$ & 0.02 & $3.0^{\mathrm{b}}$ & $3.5^{\mathrm{a}}$ & 0.02 & $<0.0001$ & $<0.0001$ & 0.13 \\
Trachea & 0.102 & 0.105 & 0.104 & 0.003 & 0.101 & 0.106 & 0.003 & 0.75 & 0.10 & 0.69 \\
Gut content & 4.39 & 4.36 & 4.06 & 0.12 & 4.1 & 4.3 & 0.10 & 0.14 & 0.10 & 0.54 \\
TENO & $8.37^{\mathrm{a}}$ & $8.55^{\mathrm{a}}$ & $7.99^{\mathrm{b}}$ & 0.13 & $7.91^{\mathrm{b}}$ & $8.69^{\mathrm{a}}$ & 0.10 & 0.019 & $<0.0001$ & 0.83 \\
\hline
\end{tabular}

${ }^{a-c}$ Means with different superscript letter within genotype and concentrate level categories in a row differ ( $p$ $<0.05)$; TENO=Total none-edible offal; Concentrate mix $(\mathrm{CM})=$ Wheat bran $(45 \%)$, maize grain $(26 \%)$ and Noug seed cake (29\%); Low $=300 \mathrm{~g} / \mathrm{d}$ CM; High $=450 \mathrm{~g} / \mathrm{d}$ CM; SEM = Standard error of the mean.

the non-edible offal spleen, penis, skin and legs, and total non-edible offal were significantly affected by genotype and concentrate level $(p<0.01)$. Total non-edible offal was lower for Washer than the other breeds, while the high level of concentrate supplementation resulted in higher non-edible offal components 
for those that showed significant effect.

\subsection{Chemical Composition of Meat}

The moisture content of the meat was higher and that of the CP content was lower $(p<0.05)$ for Washera compared to the other two sheep breeds that had similar values (Table 5). The fat and ash content of the meat was unaffected ( $p>$ $0.05)$ by genotype. The effect of concentrate level was significant $(p<0.05)$ only for fat content, the vale being higher for the high level of concentrate supplementation.

\subsection{Color and pH Measures of Meat}

Average meat color parameters were 37.11 for lightness, 11.8 for redness and 11.14 for yellowness with mean ultimate $\mathrm{pH}$ of 5.55. Meat from Rutana sheep had higher lightness and lower redness and yellowness $(p<0.05)$ than Washera sheep. Gumuz sheep had similar $(p>0.05)$ meat color parameters with Rutana, but Gumuz sheep differs from Washera only in redness (Table 6). The $\mathrm{pH}$ taken one hour after slaughter was higher but ultimate $\mathrm{pH}$ was lower $(p<0.05)$ for Rutana sheep as compared to the other breeds. Level of concentrate supplementation did not impact $(p>0.05)$ the color and $\mathrm{pH}$ of meat.

\subsection{Sensory Evaluation and Shear Force Measurement of Meat}

There were significant $(p<0.01)$ variations among the genotypes and between the concentrate levels in all sensory and shear force parameters measured (Table 7). Washera had the lowest value in all parameters, while Gumuz had only lower value than Rutana in flavor and overall acceptability $(p<0.05)$. Sensory values with exception of shear force were higher $(p<0.05)$ for high level of concentrate supplemented group.

\section{Discussion}

\subsection{Carcass Weight and Dressing Percentage}

Results of this study highlighted a significant impact of both sheep genotype and

Table 5. Proximate composition (\%) of muscle of Gumuz (GU), Rutana (RU) and Washera (WA) sheep fed grass hay basal diet supplemented with two levels of concentrate mix.

\begin{tabular}{cccccccccccc}
\hline & \multicolumn{3}{c}{ Genotype (G) } & \multicolumn{3}{c}{ Concentrate level (C) } & \multicolumn{4}{c}{$p$-value } \\
\hline Parameters & GU & RU & WA & SEM & Low & High & SEM & G & C & G $\times$ C \\
\hline Moisture & $72.8^{\mathrm{b}}$ & $72.3^{\mathrm{b}}$ & $73.2^{\mathrm{a}}$ & 0.22 & 72.9 & 72.8 & 0.17 & 0.005 & 0.879 & 0.53 \\
CP & $20.1^{\mathrm{a}}$ & $20.8^{\mathrm{a}}$ & $19.6^{\mathrm{b}}$ & 0.39 & 19.7 & 20.6 & 0.32 & 0.01 & 0.09 & 0.68 \\
Fat & 10.3 & 8.8 & 8.6 & 0.36 & $8.8^{\mathrm{b}}$ & $9.7^{\mathrm{a}}$ & 0.29 & 0.08 & 0.04 & 0.48 \\
Ash & 5.8 & 5.8 & 5.7 & 0.03 & 5.8 & 5.8 & 0.02 & 0.64 & 0.77 & 0.05 \\
\hline
\end{tabular}

${ }^{\mathrm{a}, \mathrm{b}}$ Means with different superscript letter within genotype and concentrate level categories in a row differ $(p$ $<0.05)$; $\mathrm{CP}=$ Crude protein; Concentrate mix $(\mathrm{CM})=$ Wheat bran (45\%), maize grain (26\%) and Noug seed cake (29\%); Low $=300 \mathrm{~g} / \mathrm{d}$ CM; High $=450 \mathrm{~g} / \mathrm{d}$ CM; SEM $=$ Standard error of the mean 
Table 6. Color and pH measures of muscle of Gumuz (GU), Rutana (RU) and Washera (WA) sheep fed grass hay basal diet supplemented with two levels of concentrate mix.

\begin{tabular}{cccccccccccc}
\hline & \multicolumn{3}{c}{ Genotype (G) } & \multicolumn{4}{c}{ Concentrate level (C) } & \multicolumn{3}{c}{$p$-value } \\
\hline Parameters & GU & RU & WA & SEM & Low & High & SEM & G & C & G $\times$ C \\
\hline Meat color & & & & & & & & & & \\
$\mathrm{L}^{*}$ & $34.9^{\mathrm{ab}}$ & $36.4^{\mathrm{a}}$ & $34.2^{\mathrm{b}}$ & 0.61 & 36.2 & 38.0 & 0.49 & 0.049 & 0.086 & 0.589 \\
$\mathrm{a}^{*}$ & $11.22^{\mathrm{b}}$ & $11.17^{\mathrm{b}}$ & $13.02^{\mathrm{a}}$ & 0.32 & 11.6 & 11.9 & 0.26 & 0.0006 & 0.57 & 0.948 \\
$\mathrm{~b}^{*}$ & $11.01^{\mathrm{ab}}$ & $10.66^{\mathrm{b}}$ & $11.75^{\mathrm{a}}$ & 0.30 & 10.9 & 11.3 & 0.24 & 0.0487 & 0.22 & 0.074 \\
$\mathrm{Meat} \mathrm{pH}$ & & & & & & & & & \\
$\mathrm{pH}_{1}$ & $7.01^{\mathrm{b}}$ & $6.79^{\mathrm{b}}$ & $7.88^{\mathrm{a}}$ & 0.26 & 7.05 & 7.40 & 0.21 & 0.018 & 0.26 & 0.254 \\
$\mathrm{pH}_{24}$ & $5.60^{\mathrm{a}}$ & $5.41^{\mathrm{b}}$ & $5.70^{\mathrm{a}}$ & 0.03 & 5.53 & 5.59 & 0.02 & $<0.0001$ & 0.43 & 0.142 \\
\hline
\end{tabular}

a,b Means with different superscript letter within genotype and concentrate level categories in a row differ $(p$ $<0.05) ; \mathrm{L}^{*}=$ lightness index, $\mathrm{a}^{*}=$ redness index; $\mathrm{b}^{*}=$ yellowness index; $\mathrm{pH} 1=\mathrm{pH}$ measure taken one hour after slaughter; $\mathrm{pH}_{24}=\mathrm{pH}$ measure taken 24 hours after slaughter; Concentrate mix $(\mathrm{CM})=$ Wheat bran $(45 \%)$, maize grain $(26 \%)$ and Noug seed cake (29\%); Low $=300 \mathrm{~g} / \mathrm{d}$ CM; High $=450 \mathrm{~g} / \mathrm{d}$ CM; SEM = Standard error of the mean.

Table 7. Sensory and Shear force measures of muscle of Gumuz (GU), Rutana (RU) and Washera (WA) sheep fed grass hay basal diet supplemented with two levels of concentrate mix.

\begin{tabular}{cccccccccccc}
\hline & \multicolumn{3}{c}{ Genotype (G) } & \multicolumn{3}{c}{ Concentrate level (C) } & \multicolumn{3}{c}{$p$-value } \\
\hline Parameters & GU & RU & WA & SEM & Low & High & SEM & G & C & G $\times$ C \\
\hline Tenderness & $6.70^{\mathrm{a}}$ & $6.76^{\mathrm{a}}$ & $6.61^{\mathrm{b}}$ & 0.02 & $6.56^{\mathrm{b}}$ & $6.81^{\mathrm{a}}$ & 0.02 & 0.0008 & $<0.0001$ & 0.08 \\
Juiciness & $6.79^{\mathrm{a}}$ & $6.81^{\mathrm{a}}$ & $6.68^{\mathrm{b}}$ & 0.02 & $6.65^{\mathrm{b}}$ & $6.88^{\mathrm{a}}$ & 0.01 & 0.0019 & $<0.0001$ & 0.19 \\
Flavour & $6.78^{\mathrm{b}}$ & $6.84^{\mathrm{a}}$ & $6.61^{\mathrm{c}}$ & 0.02 & $6.63^{\mathrm{b}}$ & $6.89^{\mathrm{a}}$ & 0.01 & $<0.0001<0.0001$ & 0.18 \\
OA & $6.81^{\mathrm{b}}$ & $6.88^{\mathrm{a}}$ & $6.68^{\mathrm{c}}$ & 0.01 & $6.68^{\mathrm{b}}$ & $6.90^{\mathrm{a}}$ & 0.01 & $<0.0001<0.0001$ & 0.31 \\
SRF (N/cm $\left.{ }^{2}\right)$ & $29.05^{\mathrm{a}}$ & $27.32^{\mathrm{b}}$ & $31.34^{\mathrm{a}}$ & 0.99 & $30.51^{\mathrm{a}}$ & $27.96^{\mathrm{b}}$ & 0.81 & 0.0294 & 0.0363 & 0.61 \\
\hline
\end{tabular}

${ }^{\mathrm{a}-\mathrm{c}}$ Means with different superscript letter within genotype and concentrate level categories in a row differ $(p$ $<0.05) ; \mathrm{SRF}=$ shear force; $\mathrm{OA}=$ Overall acceptability; Concentrate mix $(\mathrm{CM})=$ Wheat bran $(45 \%)$, maize grain $(26 \%)$ and Noug seed cake (29\%); Low $=300 \mathrm{~g} / \mathrm{d}$ CM; High $=450 \mathrm{~g} / \mathrm{d}$ CM; SEM = Standard error of the mean.

level of supplementation on carcass yield and dressing percentage. Similar observation has been documented in a comparative study conducted in Ethiopian sheep [11] and goat genotypes [12]. Improvement in carcass yield and dressing percentage of indigenous sheep with increasing level of supplementation as in the case of the current study is well documented [7] [23] and is a function of increased supply of nutrients for muscle development. This is supported by greater rib-eye muscle area of the high concentrate level supplemented group in this study, as rib-eye muscle area is mostly used as a tool to indicate the proportion of carcass muscling [24]. Various studies showed that supplementation had a significant and positive effect on the rib-eye muscle area [11] [25], which is in line with the result of this study.

In the current study Rutana sheep showed a better potential in carcass yield 
and dressing percentages, although the latter was not significantly different from Gumuz sheep. Devendra et al. [26] described dressing percentage as the proportion of carcass weight to body weight, a parameter that helps to assess meat productivity of animals. Nutrition influence dressing percentage through variation in weight of gut contents and variation in actual carcass weights [27]. The reason for variation in dressing percentage between Rutana and Washera sheep in the present study appeared to be due greater differences in HCW as compared to differences in SBW or EBW between the two breeds. Conversely, similar proportional increase in HCW to that of increase in SBW or EBW in Gumuz and Rutana sheep might have resulted to comparable dressing percentage values of Gumuz with Rutana sheep. Dressing percentage expressed as percentage of shrunk and empty body weight in the current study averaged $41.7 \%$ and $52.1 \%$, respectively, which was comparable to the average of $43 \%$ and $52 \%$ reported for Washera sheep [28].

\subsection{Edible and Non-Offal Components}

In Ethiopia carcass offal components are categorized into edible and non-edible based on the tradition and eating habit of the people in different parts of the country. In general, most edible and non-edible offal components was not significantly impacted by genotype and/or level of concentrate supplementation, as such tissues are of early maturing being little impacted by differences in nutritional status and growth rate of the animals. Those that were significantly affected such as the liver, GIT and heart fat appeared to be the ones that can be affected by nutritional status of the animal and consequently by differences in growth rate of genotypes [29]. The increase in liver weight with high concentrate supplementation and differences among genotypes in liver weight might be related to the storage of reserve carbohydrates such as glycogen when animals are fed with energy dense diets [30], and might be associated with difference in body mass among genotypes that proportionately increase the size of the liver [29]. According to Wester et al. [31] large amounts of digesta present in the GIT would result to net tissue growth presumably to accommodate for the increased requirement for digestion, which might have been the reason for the observed differences among genotypes and between concentrate levels in GIT weight in the current study. Differences in the weight of penis, spleen, skin and leg among genotypes and between concentrate levels appeared to be a result of a proportional increase in such components as EBW increases [32].

\subsection{Chemical Composition of Meat}

Meat quality can be evaluated through its content of protein, fat, water and ash [33]. The high moisture and low protein content of Washera sheep as compared to the other genotypes noted in this study could be associated with variations in tissue development as a result of differences in stage of physiological maturity [34]. Despite the expected inverse relationship of moisture and fat content, the 
latter however fail to differ significantly among genotypes. On the other hand sheep on the high concentrate diet recorded higher meat fat content, as dietary levels of concentrate have a positive effect on fat content of the carcass [35]. Increased concentrate intake is associated with the production of more ruminal propionate and/or higher glucose in the small intestine from non-degradable starch [36] which stimulates insulin production and consequently lipogenesis [37]. Ash content in the current study was not affected by genotype and concentrate level, which is in line with the study of Dereje et al. [12] that reported similar ash content for Bati, Hararghe highland, and Short-eared Somali goats fed different concentrate levels.

\subsection{Color and pH Measures of Meat}

Color is one of the important quality characteristics of fresh meat [38]. It can be measured numerically using a colorimeter or subjectively [39]. The higher meat lightness $\left(L^{*}\right)$ of Rutana than Washera sheep noted in this study could be a result of differences in muscle myoglobin content that could be observed among breeds [40]. The average meat lightness of Washera sheep of the present study was lower than the value of 37.2 reported for Black head Ogaden sheep of Ethiopia [41] and greater than value of 32.2 reported for Arsi-Bale and Afar sheep lambs [41]. In the current study the value of meat color coordinates ( $\mathrm{L}^{\star}$ and $\mathrm{a}^{*}$ ) for all breeds were higher than the acceptable threshold values for lightness of $\geq 34$ and redness $\left(\mathrm{a}^{*}\right)$ of $\geq 9.5$ established by consumer evaluations of fresh lamb meat [42].

The ultimate meat $\mathrm{pH}$ values obtained from this study were within the international acceptable range of meat $\mathrm{pH}$ (5.5 - 5.9) for export/import market, indicating the glycogen levels in the muscle of the meat was high enough to develop optimum level of lactic acid causing a fall in $\mathrm{pH}$ and thereby improving the shelf life of the meat [43]. Therefore, the current study showed that animals were in good physical condition with sufficient glycogen reserve at slaughter. The outcome of the current study are greater than previous finding [11] who reported the $\mathrm{pH}$ values within the range of 5.7 - 5.8 for comparative study conducted in Ethiopia sheep when the $\mathrm{pH}$ measurement was made $24 \mathrm{~h}$ after slaughter. In the present study they were a significant impact on genotype than concentrate level. The breed effect on meat $\mathrm{pH}$ in the present study might be attributed to changes in the muscle glycogen reserve at slaughter which is inversely related to the ultimate $\mathrm{pH}$ [44].

\subsection{Sensory Evaluation and Shear Force Measurement of Meat}

Quality of sheep meat is directly related to its sensory characteristics, such as tenderness, juiciness, taste, and odor [45], and the overall acceptability is highly correlated with flavor and tenderness [46]. The current finding showed a significant impact of both sheep genotype and level of concentrate supplementation on sensory characteristics. Previous studies also highlighted genotypes effect [40] 
and effect of level of concentrate feeding [47] on sensory eating quality of lamb meat. The average value of flavour and juiciness of the current study were higher than the value for flavour (3.33) and juiciness (3.47) noted for sheep in Zanzibar [48]. The differences in juiciness could be related primarily to the ability of muscles to hold water during cooking [49], and that of tenderness could be due to differences in the size of muscle fiber [50]. Differences in sensory quality of meat with level of concentrate supplementation noted in this study could be due to the fact that animal that grow and mature on a high energy diet can have improved tenderness, juiciness and flavour [39]. Generally, the eating quality scores given by the sensory panelist for all breeds and supplementation level were within the acceptable range of 6 to 9 set by AMSA [21].

The average shear force value of the current study was comparable to the finding of $29.83 \mathrm{~N} / \mathrm{cm}^{2}$ [51]. In contrast Hamdu [41] reported $26.71 \mathrm{~N} / \mathrm{cm}^{2}$ for Zanzibar sheep. Generally the sheer force value of less than $49 \mathrm{~N} / \mathrm{cm}^{2}$ is considered and acknowledged as tender [49]. Likewise Hopkins et al. [52] Shear force value of above $27 \mathrm{~N} / \mathrm{cm}^{2}$ has been recommended for Mutton to satisfy the consumers' acceptance. The lower shear force value for higher supplement level is related with higher fat content of the meat [53].

\section{Conclusion}

This study demonstrated the effect of genotype and concentrate feeding levels on slaughter performance and meat quality of Rutana, Gumuz and Washera sheep breed of Ethiopia. Among the genotypes considered in this study, Rutana sheep were more suitable for production of high carcass yield. Washera sheep are capable of producing comparable carcass yield with Gumuz sheep despite they have lower slaughter and dressing percentage. The present study demonstrates that there are differences in chemical composition and quality attributes of meat among genotypes. Generally, there existed a significant breed variation in most parameters considered in this study, which can be an opportunity to select breeds for various use and production objectives.

\section{Acknowledgements}

The authors are highly appreciated Haramaya University for allowing access to laboratory facilities and Debere Markos University for the supplementary budget during the study, Ethiopian Science and Higher Education and Ethiopian Agricultural Research Institute for their co-funding the research work. We also acknowledge Animal products veterinary drug and feed quality assessment center of Ethiopia and those who directly or indirectly contributed to the accomplishment of this study.

\section{Conflicts of Interest}

The authors declare no conflicts of interest regarding the publication of this paper. 


\section{References}

[1] Devendra, C. and McLeroy, G.B. (1982) Goat and Sheep Production in the Tropics. Intermediate Tropical Agriculture Series. Longman, London, $271 \mathrm{p}$.

[2] CSA (Central Static Agency) (2018) Agricultural Sample Survey Report on Livestock and Livestock Characteristics Addis Ababa, Ethiopia. Volume 2.

[3] Gizaw, S., Komen, H. and van Arendonk, J.A.M. (2008) Selection on Linear Size Traits to Improve Live Weight in Menz Sheep under Nucleus and Village Breeding Programs. Livestock Science, 118, 92-98. https://doi.org/10.1016/j.livsci.2008.01.006

[4] Galal, E.S.E. (1983) Sheep Germplasm in Ethiopia. Animal Genetic Resources Information, FAO, Rome, 1/83. https://doi.org/10.1017/S1014233900000018

[5] Gizaw, S. (2008) Sheep Breeds of Ethiopia: A Guide for Identification and Utilization. In: Yami, A., Awgichew, K., Gipson, T.A. and Merkel, R.C., Eds., Ethiopia Sheep and Goat Productivity Improvement Program (ESGPIP), Technical Bulletin No. 28.

[6] Dagnew, Y., Urge, M., Tadesse, Y. and Gizaw, S. (2018) Growth Performance of Gumz, Rutana and Gumz-Rutana Crossbred Sheep under On-Farm conditions in Northwestern Lowlands of Amhara Region, Ethiopia East African Journal of Veterinary and Animal Sciences, 2, 57-66.

[7] Gashu, M., Urge, M., Animut, G. and Tadesse, D. (2017) Slaughter Performance and Meat Quality of Intact and Castrated Washera Sheep Kept under Feedlot Condition. African Journal of Agricultural Research, 12, 3072-3080.

[8] Abegaz, S. (2007) In-Situ Characterization of Gumuz Sheep, under Farmer's Management in North Western Lowland of Amhara Region. Haramaya University, Haramaya, Ethiopia.

[9] Mohammed, A. (2015) Study of Sheep Mortality, under Traditional Management in North Kordofan State, Sudan. International Journal of Education and Research, 3 , 1-9.

[10] Boler, D.D. and Woerner, D.R. (2017) Perspective from the American Meat Science Association. Animal Frontiers, 7, 8-11. https://doi.org/10.2527/af.2017.0436

[11] Ayele, S., Urge, M., Animut, G. and Yusuf, M. (2018) Comparative Slaughter Performance and Carcass Quality of Three Fat Tailed Hair Sheep Supplemented Two Level of Concentrate. Tropical Animal Health and Production, 51, 187-198. https://doi.org/10.1007/s11250-018-1675-7

[12] Dereje, T., Urge, M., Animut, G. and Mekasha, Y. (2016) Growth and Carcass Characteristics of Three Ethiopian Indigenous Goats Fed Concentrate at Different Supplementation Levels. SpringerPlus, 5, 414.

https://doi.org/10.1186/s40064-016-2055-2

[13] Legese, G. and Fadiga, M. (2014) Small Ruminant Value Chain Development in Ethiopia: Situation Analysis and Trends. ICARDA/ILRI Project Report. International Center for Agricultural Research in the Dry Areas/International Livestock Research Institute, Nairobi, Kenya.

[14] BOARD (Burie Woreda Office of Agriculture and Rural Development) (2012) Annual Report, 12

[15] Abegaz, S. and Kassahun, A. (2009) Estimation of Weight and Age of Sheep and Goats. In: Yami, A. and Merkel, R.C., Eds., Ethiopia Sheep and Goat Productivity Improvement Program (ESGPIP), Technical Bulletin, No. 23.

[16] Kearl, L.C. (1982) Nutrient Requirements of Ruminants in Developing Countries. 
36-65.

[17] AOAC (Association of Official Analytical Chemists) (1990) Official Methods of Analysis. 15th Edition, Virginia, USA, 684 p.

[18] Van Soest, P.J. (1994) Nutritional Ecology of Ruminants. 2nd Edition, Cornell University Press, London, $476 \mathrm{p}$.

[19] AMSA (American Meat Science Association) (2012) Meat Color Measurement Guidelines. AMSA, Champaign, IL.

[20] AMSA (1978) Guidelines for Cookery and Sensory Evaluation of Meat. American Meat Science Association, Chicago, IL.

[21] AMSA (American Meat Science Association) (2015) Research Guidelines for Cookery, Sensory Evaluation, and Instrumental Tenderness Measurements of Meat. AMSA, Savoy, IL.

[22] SAS (Statistical Analysis System) (2003) Version 9.1. SAS Institute Inc., Cary, NC.

[23] Ayele, S., Urge, M., Animut, G. and Yusuf, M. (2017) Feed Intake, Digestibility, Growth Performance and Blood Profiles of Three Ethiopian Fat Tail Hair Sheep Fed Hay Supplemented with Two Levels of Concentrate Supplement. Open Journal of Animal Sciences, 7, 149-167. https://doi.org/10.4236/ojas.2017.72013

[24] Wolf, B.T., Smith, C. and. Sales, D.I. (1980) Growth and Carcass Composition in the Crossbred Progeny of Six Terminals Sire Breeds of Sheep. Animal Science, 31, 307-313. https://doi.org/10.1017/S0003356100024648

[25] Abuye, T., Yadav, R.K. and Diriba, G. (2018) Carcass and Non-Carcass Yield Characteristics of Horro Sheep Supplemented with Two Lablab Purpureus Cultivars and Concentrate Mixture to a Basal Diet of Natural Grass Hay. Journal of Biology, Agriculture and Health Care, 8, 65-71. https://www.iiste.org

[26] Devendra, C. and Burns, M. (1983) Goat Production in the Tropics. Common Wealth Agricultural Bureau, Farnham, Royal, England.

[27] Warmington, B.G. and Kirton, A.H. (1990) Genetic and Non-Genetic Influences on Growth and Carcasstraits of Goats. Small Ruminant Research, 3, 147-165. https://doi.org/10.1016/0921-4488(90)90089-O

[28] Hailu, A. (2008) Supplementation of Graded Levels of Concentrate Mixture on Feed Intake, Digestibility, Body Weight and Carcass Characteristics of Washera Sheep Fed Urea Treated Rice Straw. Haramaya University, Ethiopia, 64.

[29] Archimede, H.P., Pellonde, P., Etienne, T. and Alexandre, G. (2008) Growth Performance and Carcass Traits of Ovin Martinik Lambs Fed Various Ratios of Tropical Forage to Concentrate under Intensive Conditions. Small Ruminant Research, 75, 162-170. https://doi.org/10.1016/j.smallrumres.2007.10.001

[30] Lawrence, T.J. and Fowler, V.R. (1998) Growth and Carcass Composition of Ram and Wether Lambs Fed at Two Levels of Nutrition. Australian Journal of Experimental Agriculture, 26, 275-278. https://doi.org/10.1071/EA9860275

[31] Wester, T.J., Britton, R.A., Klopfenstein, T.J., Ham, G.A., Hickok, D.T. and Krehbiel, C.R. (1995) Differential Effects of Plane of Protein or Energy Nutrition on Visceral Organs and Hormones in Lambs. Journal of Animal Science, 73, 1674-1688. https://doi.org/10.2527/1995.7361674x

[32] Kirton, A.H., Fourie, P.D. and Jury, K.E. (1972) Growth and Development of Sheep III, Growth of the Carcass and Non-Carcass Components of the Southdown and Romney and Their Cross and Some Relationships with Composition. New Zealand Journal of Agricultural Research, 1, 214-227. https://doi.org/10.1080/00288233.1972.10421249 
[33] Moran, J.B. and Wood, J.T. (1986) Comparative Performance of 5 Genotypes of Indonesian Large Ruminants 3. Growth and Development of Carcass Tissues. Australian Journal of Agricultural Research, 37, 435-447. https://doi.org/10.1071/AR9860435

[34] Lawrie, R.A. and Ledward, D.A. (2006) Lawrie Meat Science. 7th Edition, Woodhead Publishing Limited Ltd., Abington, UK. https://doi.org/10.1533/9781845691615

[35] Claffey, N.A., Fahey, A.G., karane, V.G., Moloney, A.P., Monahan, F.J. and Diskin, M.G. (2018) Effect of Forage to Concentrate Ratio and Duration of Feeding on Growth and Feed Conversion Efficiency of Male Lambs. Translational Animal Science, 2, 419-427. https://doi.org/10.1093/tas/txy071

[36] Schoonmaker, J.P., Trenkle, A.H. and Beitz, D.C. (2010) Effect of Feeding Wet Distillers Grains on Performance, Marbling Deposition, and Fatty Acid Content of Beef from Steers Fed Low- or High -Forage Diets. Journal of Animal Science, 88, 3657-3665. https://doi.org/10.2527/jas.2010-2896

[37] Schoonmaker, J.P., Cecava, M.J., Faulkner, D.B., Flharty, F.L., Zerby, H.N. and Loerch, S.C. (2003) Effect of Source of Energy and Rate of Growth on Performance, Carcass Characteristics, Scottish Blackface Ewes. Animal Production, 13, 503-509.

[38] Guerrero, A., Maribel, V.V., Mari, M.C. and Carlos, S. (2013) Some Factors that Affect Ruminant Meat Quality: From the Farm to the Fork. Review. Acta Scientiarum. Animal Sciences, 35, 335-347.

[39] Amha, S. (2008) Sheep and Goat Meat Characteristics and Quality. In: Yamiand, A. and Merkel, R.C., Eds., Ethiopia Sheep and Goat Productivity Improvement Program (ESGPIP), Branna Printing Interprise, Addis Ababa, Ethiopia, 325-340.

[40] Juarez, M., Horcada, A., Alcalde, M.J., Valera, M., Polvillo, O. and Molina, A. (2009) Meat and Fat Quality of Unweaned Lambs as Affected by Slaughter Weight and Breed. Meat Science, 83, 308-313. https://doi.org/10.1016/j.meatsci.2009.05.017

[41] Lawrie, R.A. (1998) Lawrie's Meat Science. 6th Edition, Woodhead Publishing Ltd., Cambridge, England, $336 \mathrm{p}$.

[42] Danijela, Š.Z., Vera, L.L., Ljubinko, L.B., Lato, P.L., Vladimir, T.M. and Nevena, H.M. (2013) Effect of Specific Packaging Conditions on Myoglobin and Meat Color. Food and Feed Research, 40, 1-10.

[43] Girma, A., Kannan, G. and Goetsch, A.L. (2010) Effects of Small Ruminant Species and Origin (Highland and Lowland) and Length of Rest and Feeding Period on Harvest Measurements in Ethiopia. African Journal of Agricultural Research, 5, 834-847.

[44] Souza, D.A., SElaive-villaroel, A.B., Pereira, E.S. and Oliveria, R.L. (2006) Effect of Dorper Breed on Performance, Carcass and Meat Traits of Lambs Breed from Santa Inês Sheep. Small Ruminant Research, 145, 76-80.

[45] Khliji, S., van de Ven, R., Lamb, T.A., Manza, M. and Hopkins, D.L. (2010) Relationship between Consumer Ranking of Lamb Color and Objective Measures or Color. Meat Science, 85, 224-229. https://doi.org/10.1016/j.meatsci.2010.01.002

[46] Rodriguez, S. and Teixeira, A. (2009) Effect of Sex and Carcass Weight on Sensory Quality of Goat Meat of Cabrito Transmontano. Journal of Animal Science, 87, 711-715. https://doi.org/10.2527/jas.2007-0792

[47] Young, O., Priolo, A., Lane, G., Frazer, K. and Knight, T. (1999) Causes of Pastoral Flavour in Ruminant Fat. Proceedings of 45 th ICoMST, Yokohama, Japan, 420-421.

[48] Chulayo, A. and Muchenje, V. (2013) The Effects of Pre-Slaughter Stress and Sea- 
son on the Activity of Plasma Creatine Kinase and Mutton Quality from Different Sheep Breeds Slaughtered at a Smallholder Abattoir. Asian-Australasian Journal of Animal Sciences, 26, 1762-1772. https://doi.org/10.5713/ajas.2013.13141

[49] Hamdu, M.Y. (2015) Prospects for Commercial Feedlot Finishing of Sheep in Zanzibar. Master Dissertation, Sokoine University of Agriculture, Morogoro, Tanzania, 11.

[50] Furnols, F.I.M., San, J.R., Guerrero, L., Sañudo, C., Campo, M.M., Olleta, J.L., Oliver, M.A., Cañeque, V., Álvarez, I., Díaz, M.T., Branscheid, W., Wicke, M., Nute, G.R. and Montossi, F. (2006) Acceptability of Lamb Meat from Different Producing Systems and Ageing Time to German, Spanish and British Consumers. Meat Science, 72, 545-554. https://doi.org/10.1016/j.meatsci.2005.09.002

[51] Aberle, E.D., Forrest, J.C., Gerrard, D.E. and Mills, E.W. (2001) Principles of Meat Science. 4th Edition, Kendall and Hunt Publishing Co., IA.

[52] Hopkins, D.L., Hegarty, R.S., Walker, P.J. and Pethick, D.W. (2006) Relationship between Animal Age, Intramuscular Fat, Cooking Loss, $\mathrm{pH}$, Shear Force and Eating Quality of Aged Meat from Sheep. Australian Journal of Experimental Agriculture, 46, 879-884. https://doi.org/10.1071/EA05311

[53] Savell, J.W. and Cross, H.R. (1988) The Role of Fat in the Palatability of Beef, Pork, and Lamb. In: Designing Foods, Animal Product Options in the Market Place, National Academy Press, Washington DC. 